\title{
STABLE ISOTOPES OF SUBFOSSIL BAT GUANO AS A LONG-TERM ENVIRONMENTAL ARCHIVE: INSIGHTS FROM A GRAND CANYON CAVE DEPOSIT
}

\author{
Christopher M. Wurster ${ }^{*}$, Donald A. McFarlane ${ }^{2}$, Michael I. Bird ${ }^{1}$, Philippa Ascough ${ }^{3}$, And \\ Nancy Beavan Athfield ${ }^{4}$
}

\begin{abstract}
We investigated the utility of subfossil bat guano as a paleoenvironmental archive by comparing elemental ratios and $\delta^{13} \mathrm{C}, \delta^{15} \mathrm{~N}$, and $\delta \mathrm{D}$ values of various simple extracts from bulk material. Solvent-extracted guano yielded consistent $\mathrm{C}: \mathrm{N}$ and $\mathrm{N}: \mathrm{H}$ ratios, and $\delta^{13} \mathrm{C}$ values of solvent-extracted guano exhibited strong covariation with $\delta \mathrm{D}$ values, as well as with the $\delta^{13} \mathrm{C}$ values of other simple extracts (bulk guano, bulk lipid). The results suggest that reliable records are easily recovered for $\delta^{13} \mathrm{C}$, and also indicate that $\delta^{15} \mathrm{~N}$ values may have utility as a paleoenvironmental archive. Despite coeval $\delta^{13} \mathrm{C}$ values of bulk guano and solvent-extracted guano, ${ }^{14} \mathrm{C}$ ages of the different fractions did not always yield similar ages, indicating that future refinement of a suitable extraction protocol is required. Applying these protocols to an ancient bat guano deposit allowed us to infer that climate at the Grand Canyon during the late Pleistocene was more variable and generally cooler and wetter, relative to Holocene climate. We conclude that guano deposits are an underutilized, yet powerful continental paleoenvironmental archive of climate change for semi-arid and tropical regions.
\end{abstract}

\section{INTRODUCTION}

An overlooked, but potentially valuable terrestrial paleoenvironmental record is archived in stable isotope ratios of guano preserved in caves, for which extended Quaternary cave deposits are known to exist (Des Marais et al., 1980; Mizutani et al., 1992b; McFarlane et al., 2002; Bird et al., 2007). To date, several studies have shown $\delta^{13} \mathrm{C}$ and $\delta^{15} \mathrm{~N}$ values of animal feces to be a faithful tracer of dietary sources (e.g., Webb et al., 1998; Sponheimer et al., 2003). Moreover, guano from insectivorous bats is composed mostly of insect exoskeletons containing chitin, and chitin is known to be a resistant biopolymer found in the geological record as long ago as $25 \mathrm{Ma}$ (Stankiewicz et al., 1997). $\delta^{13} \mathrm{C}$ and $\delta \mathrm{D}$ values of chitin are well studied and are considered to record dietary and local water sources (e.g., Schimmelmann and DeNiro 1986b; Miller et al., 1988; Webb et al., 1998; Gröcke et al., 2006). Therefore, such a record might be recoverable from guano deposits found in Tadarida brasiliensis (the Mexican free-tailed bat) maternity roosts. Additional studies have looked at pollen sequences in guano deposits (Carrión et al., 2006; Maher, 2006), showing that multi-proxy records can be recovered.

The Mexican free-tailed bat is one of the most widely distributed mammals in the western hemisphere, common from the semi-arid and temperate regions of the southern United States to the tropical-humid environments of Brazil (Koopman, 1982; Wilkins, 1989). Up to 90 tons of guano can be deposited annually within individual maternity caves that contain populations numbering greater than one million individuals (Constantine 1970). Guano from insectivorous bats is composed mostly of finely commi- nuted insect exoskeletons (Jeuniaux, 1971; McFarlane et al., 2002). Chitin is a resistant biomacromolecule (Miller et al., 1988), and guano in arid environments is effectively mummified, virtually arresting bacterial degradation (Mizutani et al., 1992b; Shahack-Gross et al., 2004). Chitin diagenesis proceeds first by degradation of bound proteins, with the remaining chitin apparently transforming over time to aliphatic compounds (Stankiewicz et al., 1998; Briggs, 1999). During at least early diagenesis, stable isotope values of chitin and bat guano remain unchanged over up to 30 years (Schimmelmann et al., 1986; Mizutani et al., 1992b).

The Mexican free-tailed bat is a generalist insectivore with a dietary composition strongly correlated with local insect abundance (Lee and McCracken, 2002). Because insect tissue $\delta^{13} \mathrm{C}$ values reflect insect diet (Schimmelmann et al., 1993; Webb et al., 1998) and insect abundance is largely determined by available local vegetation (e.g., Pinder and Kroh, 1987; Warren and Gaston, 1992), spatially integrated variations in vegetation resulting from climate change are archived in the isotope compositions of subfossil guano deposits (Wurster et al., 2007, 2008). $\mathrm{C}_{3}$, $\mathrm{C}_{4}$, and CAM photosynthetic pathways control the carbon

\footnotetext{
*Corresponding author, christopher.wurster@jcu.edu.au

${ }^{1}$ School of Earth and Environmental Sciences, James Cook University, PO Box 6811, Cairns QLD 4870, Australia

${ }^{2}$ Keck Science Center, The Claremont Colleges, 925 North Mills Avenue, Claremont, CA 91711, USA

${ }^{3}$ AMS Group, S. U. E. R. C, Scottish Enterprise Technology Park, Rankine Avenue, East Kilbride, G75 0QF, UK

${ }^{4}$ Rafter Radiocarbon, National Isotope Centre, GNS Science, PO Box 31 312, Gracefield, Lower Hutt, New Zealand
} 


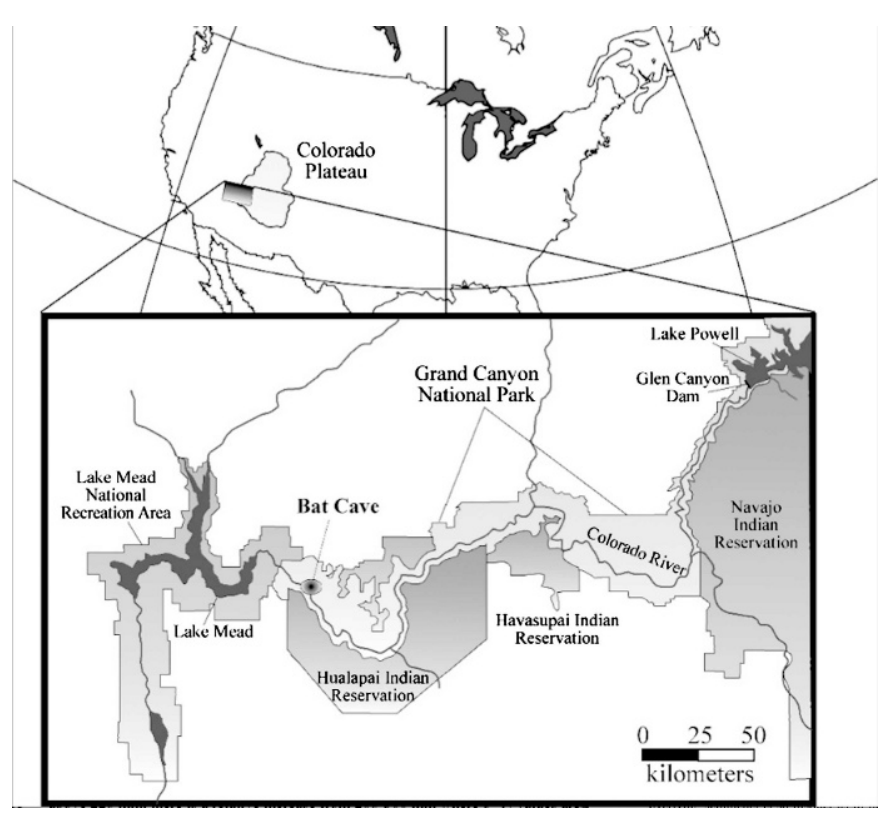

Figure 1. Study area and location of Tadarida brasiliensis maternity roost, where a guano core was excavated. Inset map after Bowers et al. 1997.

isotopic composition of plants (Ehleringer et al., 1997), and in semi-arid regions, the relative abundances of these plant types are strongly tied to local climate conditions (Paruelo and Lauenroth, 1996). Wurster et al. (2007) demonstrated a strong correlation between the relative abundance of $\mathrm{C}_{4}$ grasses and $\delta^{13} \mathrm{C}$ values of modern guano from insectivorous bats from Florida to California. Moreover, they found that $\delta^{13} \mathrm{C}$ values of guano were most strongly correlated with summer precipitation amount and winter precipitation ratio in the western United States. $\delta \mathrm{D}$ values of insect chitin reflect local environmental water, with relatively higher values indicating higher temperature, greater summer/winter precipitation ratio, and (or) lower relative humidity (Miller et al., 1988; Schimmelmann et al., 1993; Gröcke et al., 2006). Consequently, chitin $\delta^{13} \mathrm{C}$ and $\delta \mathrm{D}$ values derived from bat guano deposits are reliable archives of vegetation and regional climate conditions near the site (Wurster et al., 2007, 2008).

We present $\delta^{13} \mathrm{C}, \delta^{15} \mathrm{~N}$, and $\delta \mathrm{D}$ profiles from various simple extracts recovered from a long-term guano deposit in the Grand Canyon, USA, to evaluate further the utility of guano as a paleoenvironmental archive. We measured $\delta^{13} \mathrm{C}$ and $\delta^{15} \mathrm{~N}$ values from bulk guano, solvent-extracted guano (separated by relatively high and low $\mathrm{C}: \mathrm{N}$ ratios), and $\delta^{13} \mathrm{C}$ from the solvent extract (bulk lipids). We also measured $\delta \mathrm{D}$ values on solvent-extracted guano. In addition, we present results from AMS ${ }^{14} \mathrm{C}$ dating of bulk guano and solvent-extracted guano. We expand upon results described by Wurster et al., (2008) by comparing results obtained from different chemical fractions and including results from a deeper guano section.

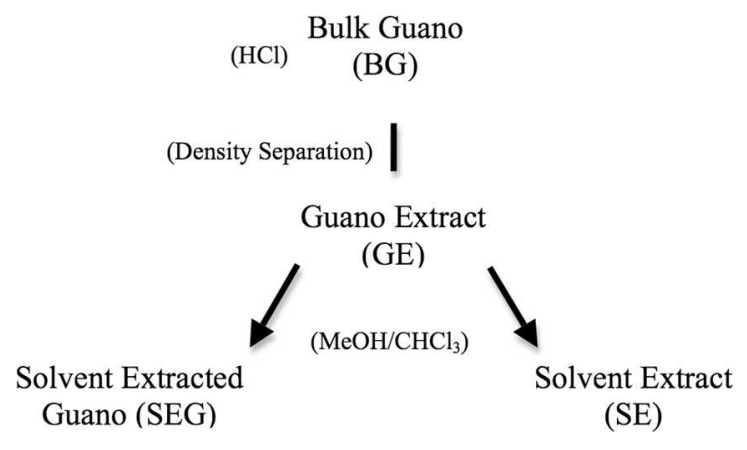

Figure 2. Flow chart of extraction methods to obtain various fractions in this study. See text for treatment details. (MeOH is methyl alcohol.)

\section{Materials And Methods}

\section{Sample Collection}

A bat guano sequence was recovered from Bat Cave, a Tadarida brasiliensis maternity roost, located $\sim 700 \mathrm{~m}$ above the Colorado River in Grand Canyon National Park, USA, in 1996 (Fig. 1). The sequences were taken in the back chamber, recently excavated to reveal an ancient bat guano deposit. Currently, the bats inhabit the front chamber, but apparently had been blocked by guano deposition from the back a considerable time ago, and thus the surface of the back deposit was not recently deposited. Two 1-m-length 5-cm-diameter pieces of PVC were driven into the guano pile and self-enclosed to extract the tube and guano without need for excavation. A surface sample was collected, termed 96-02, and a sample was taken 1.3-mdeep between the PVC cores, termed 96-03. The deeper PVC core was termed 96-05, and the shallower PVC core was termed 96-04. Collection of each core section resulted in considerable compression of approximately $65 \%$. Each section was opened in the laboratory, wetted with deionized $\mathrm{H}_{2} \mathrm{O}$ to prevent mixing during sampling, and scraped until stratigraphy was conspicuous. Two series of samples from the cores were collected and termed Pass 1 and Pass 2. Pass 1 included samples from both core 96-04 and 96-05, but only core 96-04 was resampled in Pass 2. Before Pass 2, core 96-04 was scraped again to reveal intact stratigraphy. Samples were collected at 8 -mm-thick intervals for Pass 1. For Pass 2, 4-mm-thick samples were taken from 0 to $260 \mathrm{~mm}$, and 8 -mm-thick increments thereafter.

\section{SAmple Processing and Extraction}

Several simple extraction procedures were used to isolate various organic matter components from the bulk sample. Abbreviations and a brief summary of the extraction methods are shown in Figure 2.

1. Initially, we followed methods described by Mizutani et al. (1992a) for analysis of bat guano $\delta^{13} \mathrm{C}$ values. This consisted of first decarbonating samples for at least three hours in $2 \mathrm{~N} \mathrm{HCl}$, followed by rinsing to 
neutrality with deionized $\mathrm{H}_{2} \mathrm{O}$, and finally lypholization. Between each step in this method, and the other extraction steps described below, samples were sonicated several times in $\sim 15$-minute cycles. Samples analyzed using this method are termed bulk guano (BG).

2. To concentrate the organic portion from the mineral fraction, we used heavy-liquid density separation. This method consisted of mixing $\mathrm{ZnCl}_{2}$ in $2 \mathrm{~N} \mathrm{HCl}$ to obtain a liquid with a specific gravity of 2.0. Samples were then decarbonated in this solution, ensuring that the organic portion at the surface remained saturated. After at least three hours, the sample was centrifuged for three minutes and the floatant poured onto a 12$\mu \mathrm{m}$ metal sieve. The organic portion retained on the sieve was then rinsed to neutrality with deionized $\mathrm{H}_{2} \mathrm{O}$, and lypholized. Material recovered using this method is termed the guano extract (GE).

3. We attempted to isolate natural chitin following methodology from Schimmelmann and DeNiro (1986a). Initial processing was as for the guano extract, but continued by treatment in $1 \mathrm{~N} \mathrm{NaOH}$ at $100{ }^{\circ} \mathrm{C}$ for 30 minutes followed by neutralization in deionized $\mathrm{H}_{2} \mathrm{O}$. Finally, we washed the material once in methanol followed by three times in chloroform/ methanol 2:1 by volume. After completion of solvent extraction, samples were lypholized. It was determined that the $\mathrm{NaOH}$ step resulted in a significant loss of organic material, probably due to the small amounts of starting material, the small particulate size, and the age of the sub-fossil guano. Therefore, this extraction procedure was later performed without use of $\mathrm{NaOH}$. Samples using this method, without the $\mathrm{NaOH}$, are termed the solvent-extracted guano (SEG), with samples sub-divided into high-C:N $\left(\mathrm{SEG}_{\mathrm{H}}\right)$ and low$\mathrm{C}: \mathrm{N}\left(\mathrm{SEG}_{\mathrm{L}}\right)$ samples. Two samples later determined to have $\mathrm{N}: \mathrm{H}$ ratios above 2 were discounted in the interpretation, as this may indicate contamination.

4. Finally, the solvent wash from step 3 was placed in a fume hood and permitted to fully evaporate. The recovered extract was collected and termed the solvent extract (SE).

\section{Fourier Transform Infrared Spectroscopy}

Fourier-Transform Infrared Spectroscopy is a widely used qualitative technique in the study of natural polymers and is commonly used for molecular-structure investigation of chitin and its derivatives (Duarte et al., 2002). FTIR was used to characterize the SEG, in order to confirm that this fraction represented material derived from natural chitin. For comparison, analyses were also made of fresh commercial bat guano fertilizer from a Mexican desert and a commercially obtained pure sample of $n$-acetyl-dglucosamine, the monomer of the chitin polymer. Lypholized samples were diluted by grinding with solid $\mathrm{KBr}$ and pressed into pellets prior to analysis using a Nicolet FTIR instrument. Absorbance values were determined between 4000 and $400 \mathrm{~cm}^{-1}$, and spectral bands were identified by comparison with published assignments (Duarte et al., 2002; Van de Velde and Kiekens, 2004; Wanjun et al., 2005).

Analysis of $\delta^{13} \mathrm{C}$ and $\delta \mathrm{D}$ Values, and $\mathrm{C}: \mathrm{N}$ and $\mathrm{N}: \mathrm{H}$ Elemental Ratios

We determined $\delta^{13} \mathrm{C}, \delta^{15} \mathrm{~N}$, and weight-percent organic carbon $(\% \mathrm{C})$ and nitrogen $(\% \mathrm{~N})$ by continuous-flowisotope-ratio mass spectrometry (CF-IRMS) using a ThermoFinnigan Flash 1112 Elemental Analyzer coupled by a ConFlo III to a ThermoFinnigan Delta XL Plus mass spectrometer. All $\delta^{13} \mathrm{C}$ and $\delta^{15} \mathrm{~N}$ values are reported relative to VPDB and AIR, respectively, standardized using three internal laboratory reference materials. Repeat analyses of laboratory standards yielded an external reproducibility of better than $\pm 0.2 \%$ and $0.3 \%$ for $\delta^{13} \mathrm{C}$ and $\delta^{15} \mathrm{~N}$ values, respectively. $\delta^{13} \mathrm{C}$ values were determined on samples from each extract. For samples from Pass 1, only $\delta^{13} \mathrm{C}$ analyses were performed. Both $\delta^{13} \mathrm{C}$ and $\delta^{15} \mathrm{~N}$ analyses were performed for GE and SEG samples from Pass 2, but sample size was small for $\mathrm{N}_{2}$, with an attendant decrease in reproducibility of $\delta^{15} \mathrm{~N}$ values and $\% \mathrm{~N}$. All samples were analyzed at least twice on separate runs, except in cases where not enough material was available.

$\delta \mathrm{D}$ values and weight percent $\mathrm{H}(\% \mathrm{H})$ were determined by high-temperature flash pyrolysis CF-IRMS using a ThermoFinnigan High Temperature Conversion Elemental Analyzer (TC/EA) coupled through a ThermoFinnigan ConFlo III to a ThermoFinnigan Delta XL Plus mass spectrometer. All $\delta \mathrm{D}$ values are reported relative to VSMOW-SLAP. Repeat analysis of international material IAEA $\mathrm{CH}-7$, NBS-22, and three internal laboratory standards yielded an external reproducibility of better than $\pm 3 \%$.

\section{Correction for Labile Hydrogen}

$\delta \mathrm{D}$ values were analyzed for solvent-extracted guano samples with correction for labile hydrogen exchange with atmospheric $\mathrm{H}_{2} \mathrm{O}$ vapor. Some hydrogen in complex organic matter (that component bonded to $\mathrm{N}$ or $\mathrm{O}$ ) is potentially available for exchange with the atmosphere (e.g., Schimmelmann, 1991; Wassenaar and Hobson, 2000). To correct for this exchangeable hydrogen, two standards (see below) with known $\delta \mathrm{D}_{\mathrm{n}}$ values (nonexchangeable $\delta \mathrm{D}$ values) were permitted to air equilibrate with SEG samples and analyzed together using high temperature pyrolysis CF-IRMS. Standard $\delta D_{n}$ values were used to correct for $\delta D_{n}$ values of samples (after Wassenaar and Hobson, 2000, 2003).

Because the SEG was assumed to be dominantly composed of chitin, grasshoppers were collected from Saskatoon in September and October of 2002 for one standard, and commercial bat guano was used for the 
Table 1. Determination of nonexchangeable $\delta \mathrm{D}$ value of internal reference materials used for comparative equilibration with subfossil solvent extracted guano.

\begin{tabular}{|c|c|c|c|c|c|}
\hline$\delta \mathrm{D}_{\mathrm{ta}}(\%)$ & $\delta \mathrm{D}_{\mathrm{tb}}$ & $\begin{array}{c}\text { Equilibration } \\
\text { water } \delta \mathrm{D}_{\text {wa }}(\% 0)\end{array}$ & $\begin{array}{c}\text { Equilibration } \\
\text { water } \delta \mathrm{D}_{\mathrm{wb}}(\% \mathrm{o})\end{array}$ & $\delta \mathrm{D}_{\mathrm{n}}(\% 0)$ & $\mathrm{f}_{\mathrm{e}}$ \\
\hline \multicolumn{6}{|l|}{$\mathrm{GH}$} \\
\hline 34 & -106 & 1168 & 7 & -120 & 0.10 \\
\hline-133 & -106 & -171 & 7 & -123 & 0.12 \\
\hline 34 & -133 & 1168 & -171 & -124 & 0.10 \\
\hline \multicolumn{6}{|l|}{ Guano } \\
\hline 70 & -54 & 1168 & 7 & -60 & 0.09 \\
\hline-69 & -54 & -171 & 7 & -59 & 0.07 \\
\hline 70 & -69 & 1168 & -171 & -56 & 0.09 \\
\hline
\end{tabular}

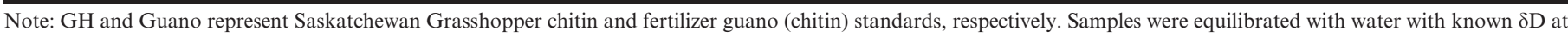

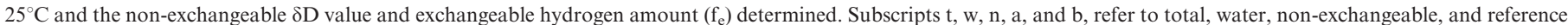

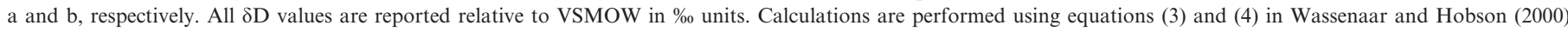

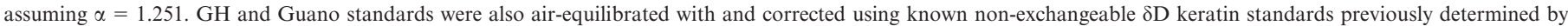

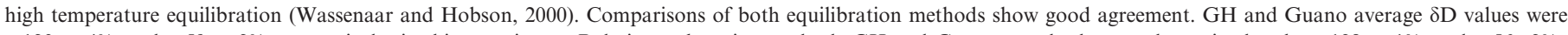

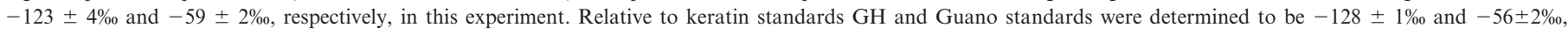
respectively.

second standard. Natural chitin from each standard was isolated using the SEG method described above (method 3 with the $\mathrm{NaOH}$ step included). Because chitin and keratin contain similar amounts of labile hydrogen at $130^{\circ} \mathrm{C}, 15.3$ $\pm 2.9 \%$ (Schimmelmann et al., 1993) and $15 \pm 3 \%$, respectively (Wassenaar and Hobson, 2003), chitin standard $\delta \mathrm{D}_{\mathrm{n}}$ values were constrained by air equilibration with known keratin standards, determined to be $-128 \pm 0.9 \%$ o and $-56.5 \pm 2.3 \%$ (assuming $80 \%$ between atmospheric water vapor and organic-matter labile hydrogen) for these grasshopper and guano standards, respectively (Table 1).

As an additional test, these standards were equilibrated with water with known $\delta \mathrm{D}$ value for three weeks at $25^{\circ} \mathrm{C}$. After equilibration was complete, samples were immediately frozen using liquid nitrogen upon removal from the water bath. The frozen samples were then placed under vacuum and lypholized. After freeze-drying was complete, samples were kept frozen, removed from vacuum, and immediately transferred to a zero-blank autosampler, where $\mathrm{He}$ was introduced to remove atmospheric water vapor. Then the samples were analyzed for $\delta \mathrm{D}$ values using the high temperature pyrolysis method described above. By this procedure, $\delta \mathrm{D}_{\mathrm{n}}$ values of $-123 \pm 4 \%$ and $-59 \pm 2 \%$, and labile hydrogen values of $11 \pm 1 \%$ and $8 \pm 1 \%$ were determined for the grasshopper and guano standards, respectively (Table 1$). \delta \mathrm{D}$ values were calculated using a provisional value of $224 \%$, estimated assuming a linear interpolation between assumed chitin values of $80 \%$ at $130^{\circ} \mathrm{C}$ (after Schimmelmann et al., 1993; Wassenaar and Hobson, 2003), and 256\% at $0^{\circ} \mathrm{C}$ (Motz, 2000). Although the water-equilibration test may have allowed a small opportunity for atmospheric water vapor to exchange with equilibrated labile hydrogen, the consistency between standard values determined in this experiment with those determined by equilibration of keratin argues against significant exchange having occurred and confirms the use of these standard values.

Additionally, the 9 to $10 \%$ labile hydrogen that we calculated is similar to Motz's (2000) result of $11 \%$ at $0^{\circ} \mathrm{C}$. $\delta D_{n}$ values of samples were determined using $\delta D_{n}$ values of standards determined by air-equilibration with keratin standards. A critical assumption is that subfossil solventextracted guano has a similar percentage of labile hydrogen. To test this assumption, ten repeat measurements on selected samples over a range of $\delta \mathrm{D}$ values were made over a year apart. All repeat measurements, corrected using guano and grasshopper chitin standards, were within reported analytical precision.

\section{RADIOCARBON DATING}

Two bulk guano (BG) samples were taken at the time the sequence was collected, one sample at the surface (96$02)$ and a second sample at 1.3 meters depth within the deposit (96-03) (corresponding to the surface and end of section 96-04), and sent for AMS radiocarbon dating at Beta Analytic. At a later time, and after initial examination of $\delta^{13} \mathrm{C}$ values analyzed from Pass 1 , seven additional samples were taken from selected depths from both cores 96-04 and 96-05 and sent to Gliwice Radiocarbon Laboratory for AMS radiocarbon measurement on BG. Because significant age reversals were noted (Fig. 3), we later submitted 11 dates to Rafter Laboratory on the solvent-extracted guano fraction to test the reliability and reproducibility of ${ }^{14} \mathrm{C}$ ages on different extracts. Samples from the deeper part of core 96-05 were often low in carbon, as organic material was much reduced in this section, so several samples from this core were near the limit of sample-size requirements. 


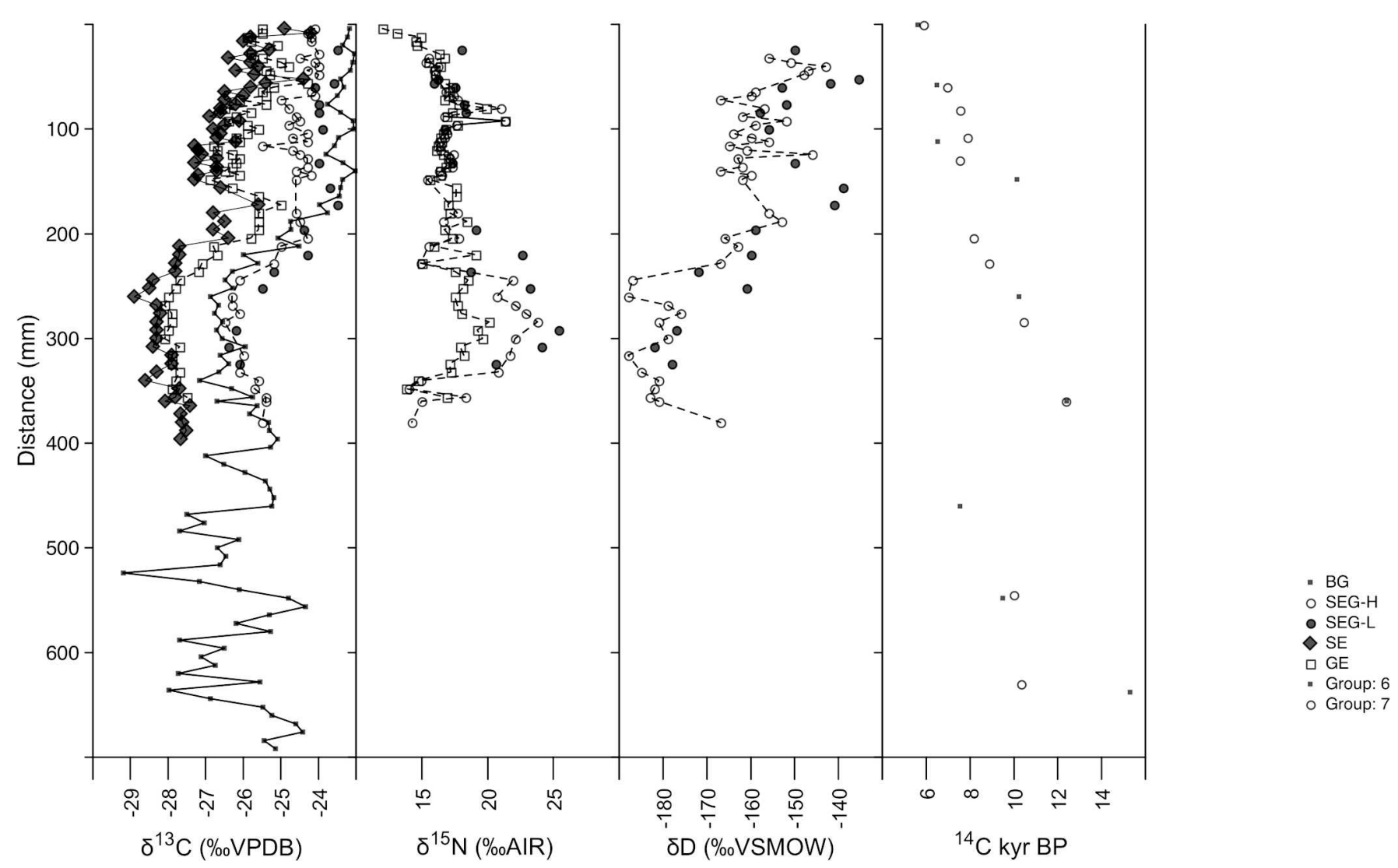

Figure 3. Comparison of stable isotope profiles of various extracts from guano deposit recovered from Bat Cave, Grand Canyon, USA. Stable isotope values for bulk guano (BG); guano extract (GE); solvent extract (SE), solvent extracted guano $\left(\mathrm{SEG}_{\mathrm{H}}\right.$; and $\left.\mathrm{SEG}_{\mathrm{L}}\right)$. See text for extraction methods.

\section{RESULTS}

Isotope Profiles, And Elemental Ratios, And INFRARED SPECTROSCOPY

All extracts have $\delta^{13} \mathrm{C}$ values that strongly covary with each other and with $\delta \mathrm{D}$ values, suggesting that a primary isotope signal is recoverable from guano material (Table 2; Fig. 3). $\delta^{15} \mathrm{~N}$ values of solvent-extracted guano samples $\mathrm{SEG}_{\mathrm{L}}$ and $\mathrm{SEG}_{\mathrm{H}}$ are less strongly covariant with $\delta \mathrm{D}$ and $\delta^{13} \mathrm{C}$ values. However, only $\delta^{15} \mathrm{~N}$ values of guano extract (GE) are not significantly related to any other isotope profile, remaining relatively consistent throughout the core. $\delta^{15} \mathrm{~N}$ values of GE and SEG profiles are similar for much of the core, but differ from 196 to $332 \mathrm{~mm}$. In this location, the solvents appear to have incorporated nitrogen-bearing compounds that were preferentially depleted in ${ }^{15} \mathrm{~N}$ in solvent-extract samples. The resulting pattern shows a large increase in $\delta^{15} \mathrm{~N}$ values at a time where $\delta^{13} \mathrm{C}$ and $\delta \mathrm{D}$ values are most negative.

$\delta^{13} \mathrm{C}$ values from bulk guano (BG) are more positive than those from equivalent GE samples. Measurements of $\delta^{13} \mathrm{C}$ values from the same aliquot of material have more negative $\delta^{13} \mathrm{C}$ values by 1 to $2 \%$, indicating that there is some fractionation of the sample associated with either density separation or particle size. Of the separated extracts, $\delta^{13} \mathrm{C}$ values of SE are the most negative, however, $\delta^{13} \mathrm{C}$ values of GE are close to those of the SE, indicating a high lipid content in these samples. Separation of SEG into $\mathrm{SEG}_{\mathrm{L}}$ and $\mathrm{SEG}_{\mathrm{H}}$ indicates that $\mathrm{SEG}_{\mathrm{L}} \delta^{13} \mathrm{C}$ values are more positive by about $0.5 \%$ than equivalent $\mathrm{SEG}_{\mathrm{H}}$ samples. Likewise, $\delta \mathrm{D}$ values were approximately $5 \%$ higher for $\mathrm{SEG}_{\mathrm{L}}$ than $\mathrm{SEG}_{\mathrm{H}}$ samples.

In general, greatly increased $\% \mathrm{C}$ and $\% \mathrm{~N}$ of separated extracts confirms that organic matter was concentrated in the floatant, increasing in amounts from 1 to $10 \%$ in the case of carbon, and thereby, also enabling nitrogen isotope analysis of the material. However, these results also indicate that not all mineral matter was removed by the density separation. Samples were split for different extracts and isotope analyses, requiring that only small amounts of material could be used for each measurement. Although isotope analyses were generally reproducible at acceptable precisions, amount percents were not as reproducible. In particular, $\% \mathrm{~N}$ for many samples was small, ranging from 0.6 to $4.0 \%$, with an average of $1.6 \%$. The case was similar for $\% \mathrm{H}$, which ranged from 0.6 to $2.5 \%$, with an average of $1.3 \%$. To determine if isotopic values are a result of varying organic components, $\mathrm{C}: \mathrm{N}$ and $\mathrm{N}: \mathrm{H}$ ratios were compared 
Table 2. Regression statistics among stable isotope profiles and elemental ratios for various extracts from a guano deposit recovered from Bat Cave, Grand Canyon, USA.

\begin{tabular}{|c|c|c|c|c|c|}
\hline Guano Extract & Covariate 1 & Covariate 2 & $F$ Value & $\mathrm{n}$ & $R$ \\
\hline \multicolumn{6}{|l|}{ Pre-Transition } \\
\hline & $\delta^{13} \mathrm{C}_{\mathrm{GE}}$ & $\delta^{13} \mathrm{C}_{\mathrm{SEG}}$ & $259.91^{\mathrm{a}}$ & 1,40 & 0.93 \\
\hline & $\delta^{13} \mathrm{C}_{\mathrm{GE}}$ & $\delta^{13} \mathrm{C}_{\mathrm{SE}}$ & $214.65^{\mathrm{a}}$ & 1,39 & 0.91 \\
\hline & $\delta^{13} \mathrm{C}_{\mathrm{SEG}}$ & $\delta^{13} \mathrm{C}_{\mathrm{SE}}$ & $217.34^{\mathrm{a}}$ & 1,43 & 0.90 \\
\hline & $\delta \mathrm{D}_{\mathrm{SEG}}$ & $\delta^{13} \mathrm{C}_{\mathrm{SEG}}$ & $71.26^{\mathrm{a}}$ & 1,39 & 0.75 \\
\hline & $\delta^{15} \mathrm{~N}_{\mathrm{GE}}$ & $\delta^{15} \mathrm{~N}_{\mathrm{SEG}}$ & $68.20^{\mathrm{a}}$ & 1,35 & 0.81 \\
\hline \multicolumn{6}{|l|}{ Pre-Transition } \\
\hline & $\delta^{13} \mathrm{C}_{\mathrm{SEG}}$ & $\delta \mathrm{D}_{\mathrm{SEG}}$ & $7.85^{\mathrm{b}}$ & 1,20 & 0.51 \\
\hline Transition & $\delta^{13} \mathrm{C}_{\mathrm{SEG}}$ & $\delta \mathrm{D}_{\mathrm{SEG}}$ & $362^{\mathrm{a}}$ & 16 & 093 \\
\hline \multicolumn{6}{|l|}{ Post-Transition } \\
\hline & $\delta^{13} \mathrm{C}_{\mathrm{SEG}}$ & $\delta \mathrm{D}_{\mathrm{SEG}}$ & $10.99^{\mathrm{a}}$ & 1,9 & 0.83 \\
\hline 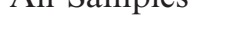 & $\mathrm{C}: \mathrm{N}$ & $\delta^{13} \mathrm{C}_{\mathrm{GE}}$ & $208.38^{\mathrm{a}}$ & 1,59 & -0.88 \\
\hline & $C: N$ & $\delta^{13} \mathrm{C}_{\mathrm{SEG}}$ & 0.13 & 1,38 & -0.07 \\
\hline & $\mathrm{N}: \mathrm{H}$ & $\delta^{13} \mathrm{C}_{\mathrm{SEG}}$ & 4.56 & 1,34 & 0.4 \\
\hline & $\mathrm{C}: \mathrm{N}$ & $\delta D_{\mathrm{SEG}}$ & 0.93 & 1,38 & 0.05 \\
\hline & $\mathrm{N}: \mathrm{H}$ & $\delta \mathrm{D}_{\mathrm{SEG}}$ & 2.77 & 1,34 & 0.28 \\
\hline Transition & $\mathrm{C}: \mathrm{N}$ & $\delta^{13} \mathrm{C}_{\mathrm{SEG}}$ & 0.01 & 16 & -0.47 \\
\hline & $\mathrm{C}: \mathrm{N}$ & $\delta \mathrm{D}_{\mathrm{SEG}}$ & 1.00 & 1,6 & -0.38 \\
\hline & $\mathrm{N}: \mathrm{H}$ & $\delta^{13} \mathrm{C}_{\mathrm{SEG}}$ & 0.93 & 1,6 & 0.37 \\
\hline & $\mathrm{N}: \mathrm{H}$ & $\delta \mathrm{D}_{\mathrm{SEG}}$ & 0.99 & 1,6 & 0.38 \\
\hline
\end{tabular}

${ }^{\mathrm{a}}$ Significant at or beyond 0.001 .

${ }^{\mathrm{b}}$ Significant at or beyond 0.025 .

Note: Subscripts refer to extraction types (see text for methods) Guano Extract (GE), Solvent Extracted High-C:N Guano (SEG), Solvent Extract (SE).

to $\delta^{13} \mathrm{C}$ and $\delta \mathrm{D}$ values (Table 2). Carbon-13 values of the GE have a strong and significant relationship with $\mathrm{C}: \mathrm{N}$ ratios. However, $\delta^{13} \mathrm{C}$ values of the SEG did not have a significant relationship with $\mathrm{C}: \mathrm{N}$ and $\mathrm{N}: \mathrm{H}$ ratios. Samples with $\mathrm{C}: \mathrm{N}$ ratios between 6 and 8 , and $\mathrm{N}: \mathrm{H}$ ratios below 2.5 had no significant relationship with $\delta^{13} \mathrm{C}$ nor $\delta \mathrm{D}$ values (Table 2). To further test the effect of diagenesis on the $\mathrm{SEG}_{\mathrm{H}}, \mathrm{C}: \mathrm{N}$ and $\mathrm{N}: \mathrm{H}$ ratios were grouped into several subdivisions based on a large transition in $\delta^{13} \mathrm{C}, \delta \mathrm{D}$, and $\delta^{15} \mathrm{~N}$ values that occurred from 260 to $150 \mathrm{~mm}$ in section 96-04: (1) prior to this transition, (2) within this transition, and (3) after this transition. Neither $\mathrm{C}: \mathrm{N}$ nor $\mathrm{N}: \mathrm{H}$ ratios were significantly different among these time periods (Kruskal-Wallis test, $H=1.58, p=0.45 ; H=1.85, p=$ 0.40 , respectively), supporting the interpretation that this large isotopic change did not occur due to diagenesis.

Relative to the reference spectrum of $n$-acetyl- $d$-glucosamine, Fourier-transform infrared spectroscopy of fresh bat guano shows a broadening of the IR bands, typical in natural polymers (Duarte et al., 2002). The spectra of both modern comparison materials demonstrated a range of signals relating to the molecular structure of chitin (Fig. 4). Bands at 3448, 3269, and $2934 \mathrm{~cm}^{-1}$ represent $\mathrm{OH}$ stretching and symmetric NH stretching in secondary amides, respectively, while $\mathrm{CH}$ symmetric and asymmetric stretching vibrations were observed between 2828 and $2962 \mathrm{~cm}^{-1}$ (Seoudi et al., 2005). Detailed information is contained in the fingerprint region at $900-1700 \mathrm{~cm}^{-1}$. Here, bands at 1653 and $1557 \mathrm{~cm}^{-1}$ relate to $\mathrm{CO}$ stretching in amide $\mathrm{I}$ and $\mathrm{N}-\mathrm{H}$ deformation of amine II, and at $1381 \mathrm{~cm}^{-1}$ to $\mathrm{CH}$ bending vibration in chitin (Van de Velde and Kiekens, 2004; Seoudi et al., 2005). Finally, bands at 1030 to $1156 \mathrm{~cm}^{-1}$ are diagnostic for ring and bridge $\mathrm{C}-\mathrm{O}-\mathrm{C}$ vibrations in the saccharide monomer (Duarte et al., 2002). The IR spectra of SEG (subfossil bat guano on Figure 4) contained a lower range of signals, which are much broader than the modern samples, but the position of these signals corresponds to the bands that characterize the chitin macromolecule. The merging of bands in the region 1550 to $1690 \mathrm{~cm}^{-1}$ indicates a higher degree of deacetylation in SEG than in modern material, while distinct peaks at 1030 to $1156 \mathrm{~cm}^{-1}$ are replaced by a broad signal with discernable peaks at 1030 and $1076 \mathrm{~cm}^{-1}$, suggesting partial break up of the polysaccharide structure and rupture of the $\beta$-glycosidic-linkages. Overall, the infrared spectra of SEG appear diagnostic of significantly degraded chitin, as reported previously (Wanjun et al., 2005).

\section{RADiocarbon Dates}

Radiocarbon dates do not increase monotonically on bulk guano (BG) samples taken from both sections 96-05 


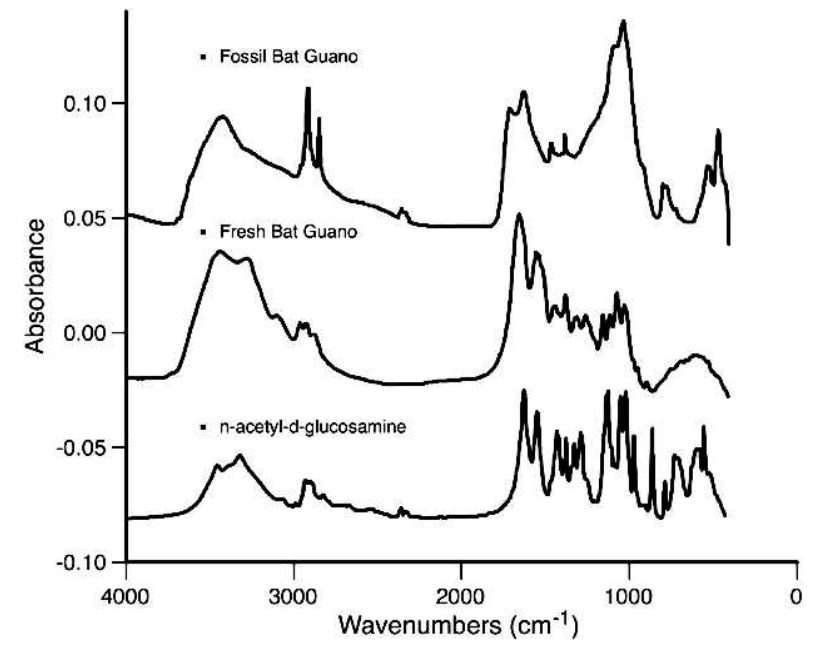

Figure 4. Comparison of infrared spectra of subfossil guano (DAM 96-02), fresh bat guano, and $n$-acetyl- $d$-glucosamine (top to bottom) showing major chitin peaks preserved in subfossil guano.

and 96-04, and thus a reliable chronology cannot be developed for the entire sequence (Table 3; Fig. 3). Two dates from section 96-05 are conspicuously young, and several dates from 58 to $262 \mathrm{~mm}$ suggest periods of rapid deposition separated by a hiatus (Table 3, Fig. 3). However, a second set of ${ }^{14} \mathrm{C}$ ages on solvent extracted guano from section 96-04 displayed a more linear deposition rate. Deeper in the deposit, two SEG radiocarbon measurements from core 96-05 also appear to suffer from contamination. These samples are likely to have suffered from small quantities of carbon submitted and are thus more likely to have been contaminated. Moreover, more than seven separate solvent washes were performed on these samples, because coloration of the solvent indicated a high and consistent presence of lipid components, and it is unlikely that all lipids were removed. Many BG dates are similar to SEG dates, again suggesting broad reliability. One measurement from section 96-05 $\left(15,300 \pm 100{ }^{14} \mathrm{C}\right.$ yr BP uncalibrated, sample GdA-322) suggests a continued relatively linear deposition rate when compared with SEG radiocarbon measurements from section 96-04.

\section{Discussion}

\section{$\delta^{13} \mathrm{C}, \delta \mathrm{D}$, and $\delta^{15} \mathrm{~N}$ Values of Guano Extracts}

$\delta^{13} \mathrm{C}$ values on all extracts show a similar pattern and are strongly covariant (Table 2 ). $\delta \mathrm{D}$ values measured on the solvent-extracted guano also exhibit a similar pattern with strong covariation. In particular, each isotopic profile displays a distinct stepwise increase between approximately 260 and $150 \mathrm{~mm}$. The similarity and especially the timing of this transition in each isotopic profile, regardless of chemical fraction, argues that this rise is an environmental signal and not a diagenetic effect. Mizutani and Wada (1988) found little overall fractionation in $\delta^{13} \mathrm{C}$ during soil organic matter decomposition, in stark contrast to $\delta^{15} \mathrm{~N}$ values. In this study, $\delta^{15} \mathrm{~N}$ values are relatively constant, but more positive than the originally deposited guano based on $\delta^{15} \mathrm{~N}$ values of modern guano (Wurster et al., 2007). This finding is consistent with post-depositional modification to isotopic composition associated with volatilization of ammonia, described previously for seabird guano (Mizutani and Wada, 1988). Although we expected $\delta \mathrm{D}$ values to be more prone to error, there was strong covariation between $\delta \mathrm{D}$ values and $\delta^{13} \mathrm{C}$ values. Some contamination was expected from hydrogen released from a residual mineral component because samples were not completely organic. Nonetheless, the strong correlation between $\delta \mathrm{D}$ and $\delta^{13} \mathrm{C}$ indicates that the $\delta \mathrm{D}$ profile is not overly influenced by degradation or contamination, with large changes (over $50 \%$ ) in $\delta \mathrm{D}$ values that are likely attributable to environmental effects.

\section{Diagenesis and Elemental Ratios}

The guano-extract fraction had $\delta^{13} \mathrm{C}$ values similar to the solvent-extract fraction, with values strongly correlated with C:N. However, after a complete solvent wash, there was a lack of significant covariation between $\delta^{13} \mathrm{C}$ values and $\mathrm{C}: \mathrm{N}$ ratios of solvent-extracted guano. To further test influence of diagenesis, a nonparametric Kruskal-Wallis test was performed by splitting $\mathrm{C}: \mathrm{N}$ and $\mathrm{N}: \mathrm{H}$ ratios in three groups: pre-transition, transition, and post-transition (see results section for definitions). No significant difference was found between these groups and $\mathrm{C}: \mathrm{N}$ and $\mathrm{N}: \mathrm{H}$ ratios. $\delta^{13} \mathrm{C}$ values are expected to covary with elemental ratios in part because natural chitin is tightly bound to protein and partially de-acetylated, especially in sclerotized insect cuticles (Schimmelmann and DeNiro, 1986a). Both serve to decrease the $\mathrm{C}: \mathrm{N}$ ratio from the 6.9 value of theoretical $n$-acetyl- $d$-glucosamine. The presence of lipids, however, will serve to increase the $\mathrm{C}: \mathrm{N}$ ratio. Both the acetyl group of chitin and lipids have more negative $\delta^{13} \mathrm{C}$ values compared to the $n$-acetyl- $d$-glucosamine polysaccharide (Schimmelmann and DeNiro, 1986a). Therefore, chemical changes should invariably lead to strong correlations between elemental ratios and isotope values. Because the cores are retrieved from a bat guano cave, insectivorous bat guano is dominantly composed of finely comminuted insect exoskeletons (McFarlane et al., 2002), and the C:N and $\mathrm{N}: \mathrm{H}$ ratios are close to those of theoretical chitin. It follows that the solvent-extracted guano represents natural chitin from insects deposited by bats through the Holocene, albeit with much of the protein degraded. This was confirmed by the infrared spectra. Therefore, we conclude that $\delta^{13} \mathrm{C}$ and $\delta \mathrm{D}$ values of both extracts are reliable for environmental interpretation, but confidence increases when selecting only samples within a narrow $\mathrm{C}: \mathrm{N}$ range. 
Table 3. Subfossil guano samples submitted for radiocarbon dating.

\begin{tabular}{|c|c|c|c|c|}
\hline Sample Name & Extract & $\begin{array}{l}\text { Conventional }{ }^{14} \mathrm{C} \\
\text { age }(\mathrm{yr} \mathrm{BP} \pm 1 \sigma)\end{array}$ & Laboratory Number & Laboratory \\
\hline $96-02$ & BG & $5620 \pm 70$ & Beta \#95152 & Beta Analytic \\
\hline $96-02$ & SEG & $5881 \pm 35$ & NZA 27606 & GNS \\
\hline \multicolumn{5}{|l|}{ Section 96-04 } \\
\hline $56-60 \mathrm{~mm}$ & BG & $6490 \pm 50$ & GdA-494 & Gliwice \\
\hline $58-62 \mathrm{~mm}$ & SEG & $6957 \pm 35$ & NZA 27608 & GNS \\
\hline $80-84 \mathrm{~mm}$ & SEG & $7550 \pm 50$ & GdA-696 & Gliwice \\
\hline $100-106 \mathrm{~mm}$ & SEG & $7872 \pm 35$ & NZA 27609 & GNS \\
\hline $108-116 \mathrm{~mm}$ & BG & $6530 \pm 35$ & GdA-540 & Gliwice \\
\hline $128-132 \mathrm{~mm}$ & SEG & $7530 \pm 40$ & GdA-695 & Gliwice \\
\hline $144-152 \mathrm{~mm}$ & TOC & $10130 \pm 60$ & GdA-319 & Gliwice \\
\hline $202-206 \mathrm{~mm}$ & SEG & $8151 \pm 35$ & NZA 27607 & GNS \\
\hline $226-230 \mathrm{~mm}$ & SEG & $8858 \pm 35$ & NZA 28163 & GNS \\
\hline $256-264 \mathrm{~mm}$ & BG & $10230 \pm 60$ & GdA-321 & Gliwice \\
\hline $280-288 \mathrm{~mm}$ & SEG & $10438 \pm 45$ & NZA 27626 & GNS \\
\hline $96-03$ & $\mathrm{BG}$ & $12400 \pm 90$ & Beta \#95153 & Beta Analytic \\
\hline $96-03$ & SEG & $12371 \pm 55$ & NZA 27627 & GNS \\
\hline \multicolumn{5}{|l|}{ Section 96-05 } \\
\hline $96-104 \mathrm{~mm}$ & BG & $7550 \pm 40$ & GdA-318 & Gliwice \\
\hline $180-190 \mathrm{~mm}$ & SEG & $9991 \pm 45$ & NZA 27628 & GNS \\
\hline $184-192 \mathrm{~mm}$ & $\mathrm{BG}$ & $9490 \pm 50$ & GdA-320 & Gliwice \\
\hline $270-280 \mathrm{~mm}$ & SEG & $10323 \pm 45$ & NZA 27629 & GNS \\
\hline $274-280 \mathrm{~mm}$ & $\mathrm{BG}$ & $15300 \pm 100$ & GdA-322 & Gliwice \\
\hline
\end{tabular}

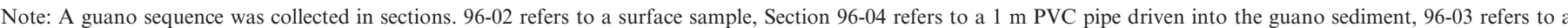

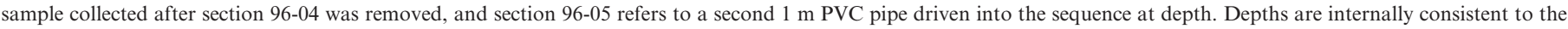
section.

\section{RADiocarbon DATES}

Washing samples with an alkaline treatment resulted in a large reduction in retrieved organic matter, and therefore, initially only acid treatment, as used in the preparation of bulk guano (BG) samples, was employed at Gliwice radiocarbon facilities. Alkaline treatment is used to remove organics that are considered more mobile, and BG samples should be considered potentially problematic. Later, we investigated the reliability of solvent-extracted guano (SEG) for radiocarbon measurement, because two independent studies had found only acid/solvent treatment necessary to obtain radiocarbon dates on insect cuticles that were consistent with radiocarbon dates on more traditional substances (peat/cellulose) in a well-constrained depositional environment (Hodgins et al., 2001; Tripp et al., 2004). Such a protocol substantially improved our confidence in the chronology, where only one reversal was noted for the upper section (96-04). Although $\delta^{13} \mathrm{C}$ values of all fractions we investigated covaried, it may be that a large part of the lipid fraction is contaminated by younger carbon, consistent with its possible diagenetic origin (Briggs, 1999). Further work in tropical guano sequences has suggested improved sample extraction methods that can yield more reliable radiocarbon measurements (Wurster et al., 2009, 2010). Wurster et al. (2009) suggested a radiocarbon pre-treatment for cave guano that included solvent washing and alkaline treatment. They found young-carbon contamination on material that was assumed to be dead on solvent extraction, whereas radiocarbon measurements on SEG and BG with traditional ABA processing from that same material were found to be within 1-sigma error of background. Together these results suggest that in addition to an acid wash, solvent extraction and alkaline treatment should be preformed prior to radiocarbon measurements.

Radiocarbon measurements of SEG from the upper section, 96-04, are considered reliable. However, dates of one BEG and two SEG samples are younger than the radiocarbon measurement from sample 96-03 taken between sections 96-04 and 96-05, leaving only one out of four radiocarbon measurements from core 96-05 older with depth when compared with the 96-04 core. Importantly, there was a large decrease in \% $\mathrm{C}$ for samples from the lower part of 9605. Carbon abundances of samples taken throughout the sequence tended to decrease with depth, and so samples from section 96-04 were generally $>10 \%$, whereas samples taken from 96-05 were generally below $<1 \%$. We consider the radiocarbon measurements on samples with such low carbon abundances to be problematic. Moreover, several lines of reasoning suggest that 96-05 is older than section 96-04: (1) 
Carbon abundances tended to decrease with depth, (2) similar $\delta^{13} \mathrm{C}$ values of different fractions between end samples of section 96-04 and the beginning section of 96-05 suggest a continuation of the sequence, and (3) Section 96-05 is deeper in the sequence. Taken independently, radiocarbon measurements of section 96-05 can be interpreted as a Holocene section, but the low carbon abundances and distinct $\delta^{13} \mathrm{C}$ values (more variable and lower than section 96-04), and depth in the deposit argue against this interpretation. Although, the guano might deform and flow with depth, it is more likely that the radiocarbon measurements are compromised in this deeper section. Thus, we interpret section 96-05 as being late Pleistocene, but cannot provide a better age estimation.

\section{Climate Interpretation Inferred from Stable Isotope Profiles of Bat Guano Deposits}

We have previously presented an interpretation of environmental change using $\delta^{13} \mathrm{C}$ and $\delta \mathrm{D}$ values of $\mathrm{SEG}_{\mathrm{H}}$ part of the solvent-extracted guano (Wurster et al., 2008) from core 96-04. Below, we expand this interpretation by including $\delta^{15} \mathrm{~N}$ values and extending the $\delta^{13} \mathrm{C}$ profile to include the deeper section (96-05). $\delta^{13} \mathrm{C}$ values of insect chitin are dependent on the animal's diet (Schimmelmann and DeNiro, 1986b); (Webb et al., 1998). Tadarida brasiliensis is an opportunistic feeder, and has been demonstrated to have dietary insect ratios in the same proportion as local availability (Lee and McCracken, 2002). Wurster et al. (2007) demonstrated $\delta^{13} \mathrm{C}$ values of insectivorous bats to be a strong predictor of modeled $\mathrm{C}_{4}$ grass abundance in the western United States. Therefore, $\delta^{13} \mathrm{C}$ values of bat guanoderived chitin reflect local vegetation, and any excursions in $\delta^{13} \mathrm{C}$ values of subfossil guano will be directly related to changes in average $\delta^{13} \mathrm{C}$ values of local vegetation, in turn reflecting local climatic conditions.

$\delta \mathrm{D}$ values of chitin reflect both metabolic and drinkingwater sources of insects, and they are correlated with $\delta \mathrm{D}$ values in local precipitation and mean annual temperature (Gröcke et al., 2006). In the Grand Canyon, $\delta \mathrm{D}$ values of the Colorado River are lower than those from regional precipitation (Coplen and Kendall, 2000), reflecting higher latitude and altitude sources in its upper catchment. The total variation in $\delta \mathrm{D}$ values of $\mathrm{SEG}_{\mathrm{H}}$ is over $50 \%$, and this cannot be accounted for solely by a change in mean temperature (e.g., Miller et al., 1988). Instead, changing $\delta D$ values of subfossil bat guano likely indicates a change in source or seasonality of precipitation or in plant water-use preference. Higher $\delta \mathrm{D}$ values of $\mathrm{SEG}_{\mathrm{H}}$ are expected from a greater summer precipitation fraction (more relative monsoonal moisture). Additionally, changing plant preference for summer $\delta \mathrm{D}$ values may be incorporated in the signal, which would likely occur if there were an increase in the relative abundance of $\mathrm{C}_{4}$ vegetation (Schwinning et al., $2002,2003)$. Therefore, higher $\delta \mathrm{D}$ values reflect one or more of higher temperatures, lower humidity, and higher summer precipitation fraction. Coeval increases in $\delta^{13} \mathrm{C}$ and $\delta \mathrm{D}$ values are thought to reflect increased monsoonal activity (Wurster et al., 2007, 2008).

We previously interpreted environmental change using $\mathrm{SEG}_{\mathrm{H}} \delta^{13} \mathrm{C}$ and $\delta \mathrm{D}$ isotope profiles from core 96-04 (ca. 5,000 to $12,000{ }^{14} \mathrm{C}$ yr BP) (Wurster et al., 2008). Grand Canyon climate was interpreted to be cool and possibly drier during the Younger Dryas stade, but modern monsoonal conditions arrived gradually by 9 calibrated ka BP. $\delta^{15} \mathrm{~N}$ values of chitin have been linked to arthropod trophic level and diet (Schimmelmann et al., 1998), therefore changing $\delta^{15} \mathrm{~N}$ values of bat guano through time may broadly indicate changing dietary sources and trophic level. Relatively high $\delta^{15} \mathrm{~N}$ values are not uncommon in semi-arid regions. Modern bat guano $\delta^{15} \mathrm{~N}$ values are reported to be 14 to $20 \%$ in New Mexico, USA, and Sonora, Mexico (Mizutani et al., 1992a; McFarlane et al., 1995), and $\delta^{15} \mathrm{~N}$ values of bat muscle tissue are 15 to $20 \%$ in arid regions of Venezuela (Nassar et al., 2003). Mammals in more arid regions typically have higher $\delta^{15} \mathrm{~N}$ values (e.g., Sealy et al., 1987), possibly through an increased recycling of body nitrogen with increased water conservation (e.g., Sponheimer et al., 2003). Although, comparatively little work has been done on insect $\delta^{15} \mathrm{~N}$ values, increased $\delta^{15} \mathrm{~N}$ values may be linked with increasing aridity. $\delta^{15} \mathrm{~N}$ values of solvent-extracted guano show a large increase in $\delta^{15} \mathrm{~N}$ values at a time when $\delta^{13} \mathrm{C}$ and $\delta \mathrm{D}$ values are most negative. Although $\delta \mathrm{D}$ values are generally more negative below relative to above $228 \mathrm{~mm}$, there is a relative increase from 268 to $300 \mathrm{~mm}$ where $\delta^{15} \mathrm{~N}$ values are maximal, and radiocarbon measurements indicate this depositional period to be coincident with the Younger Dryas stade. If higher $\delta^{15} \mathrm{~N}$ values of $\mathrm{SEG}_{\mathrm{H}}$ are a reflection of moisture stress, then these data can be interpreted as additional support for Wurster et al.'s (2008) contention of a drier Younger Dryas stade in the Grand Canyon interpreted from an increase in $\delta \mathrm{D}$ values at this time.

Although complete confidence in radiocarbon dates is lacking for core 96-05, the available evidence suggests this guano deposit captures a period greater than $\sim 12.4{ }^{14} \mathrm{C}$ ka and extends into the late Pleistocene. Below $400 \mathrm{~cm}, \delta^{13} \mathrm{C}$ values from bulk guano are lower and more variable then above. Unfortunately, radiocarbon results from low- $\% \mathrm{C}$ samples are less reliable and limit our current ability to further interpret climate change beyond $12.4{ }^{14} \mathrm{C}$ ka. However, previous studies in the region using other proxies have found the late Pleistocene to be cooler and wetter, but these studies provide only low-resolution data (Thompson et al., 1993; Cole and Arundel, 2005). We plan further investigation of the bat guano deposit reported on in this study, which may yet yield a sequential record of climate change to better understand Late Pleistocene and possibly LGM climate.

\section{Conclusions}

Diagenesis does not appear to have significantly masked an interpretable environmental signal in $\delta^{13} \mathrm{C}$ or 
$\delta \mathrm{D}$ profiles of bulk guano, guano extract, solvent-extracted guano, or solvent extract from this long-term guano deposit in the southwestern US. Although diagenetic influences cannot be completely ruled out, both the covariations among various extracts and the lack of significant covariation between elemental ratios and isotope values for the extracts, as well as the lack of significant differences between elemental ratios and age attest to a lack of significant diagenetic influence. Solventextracted guano with $\mathrm{C}: \mathrm{N}$ ratios within a limited range is the best chemical fraction for detailed analysis, because elemental ratios in the material can be used as a guide to the likelihood of diagenesis or contamination. Solvent extracts may be bacterially and/or post-depositionally derived, although the strong and significant covariation with the SEG, at least for $\delta^{13} \mathrm{C}$ values, suggests that the $\mathrm{SE}$ may nonetheless be a satisfactory material for rapid analysis. $\delta^{13} \mathrm{C}$ values of the GE fractions are the most unreliable, because they tend to be unduly influenced by the proportion of lipids present, but despite this complication, the large changes observed in this fraction are still broadly related to environmental change. Although radiocarbon dates on BG are not necessarily reliable and a definitive protocol still needs to be developed in order to provide full confidence in the chronology of the deeper sections of the core, we conclude in general terms that climate in the Grand Canyon during the latest Pleistocene was cooler and wetter, with more variability than was the case during the Holocene.

\section{ACKNOWLEDGEMENTS}

We thank A. Zazzo, E. Dufour, and A. Deifendorf for discussions, and are grateful to R. Keeler and A. Fincham for assistance in the field and T. Prokopiuk, J. Scott, S. Francis, I. González-Alvarez, and Kelly Sutton for analytical assistance. Geological Society of America, National Speleological Society, Syracuse University, Sigma $\mathrm{Xi}$, Karst Research Grant, and NERC Large Grant NE/ D001501 supported this research. The guano core was collected under a National Parks permit to D. A. McFarlane.

\section{REFERENCES}

Bird, M.I., Boobyer, E.M., Bryant, C., Lewis, H.A., Paz, V., and Stephens, W.E., 2007, A long record of environmental change from bat guano deposits in Makangit Cave, Palawan, Philippines: Earth and Environmental Science Transactions of the Royal Society of Edinburgh, v. 98, p. 59-69.

Bowers, J.E., Webb, R.H., and Pierson, E.A., 1997, Succession of desert plants on debris flow terraces, Grand Canyon, Arizona, USA: Journal of Arid Environments, v. 36, p. 67-86.

Briggs, D.E.G., 1999, Molecular taphonomy of animal and plant cuticles: selective preservation and diagenesis: Philosophical Transactions of the Royal Society B: Biological Sciences, v. 354, p. 7-17.

Carrión, J.S., Scott, L., and Marais, E., 2006, Environmental implications of pollen spectra in bat droppings from southeastern Spain and potential for palaeoenvironmental reconstructions: Review of Palaeobotany and Palynology, v. 140, p. 175-186.

Cole, K.L., and Arundel, S.T., 2005, Carbon isotopes from fossil packrat pellets and elevational movements of Utah agave plants reveal the Younger Dryas cold period in Grand Canyon, Arizona: Geology, v. 33, p. 713-716.

Constantine, D.G., 1970, Bats in relation to the health, welfare, and economy of man: Biology of Bats, v. 2, p. 319-449.

Coplen, T.B., and Kendall, C., 2000, Stable hydrogen and oxygen isotope ratios for selected sites of the U.S. Geological Survey's NASQAN and benchmark surface-water networks: U.S. Geological Survey, OpenFile Report $00-160$, p. 38-44.

Des Marais, D.J., Mitchell, J.M., Meinschein, W.G., and Hayes, J.M., 1980, The carbon isotope biogeochemistry of the individual hydrocarbons in bat guano and the ecology of the insectivorous bats in the region of Carlsbad, New Mexico: Geochimica et Cosmochimica Acta, v. 44 , p. $2075-2086$.

Duarte, M.L., Ferreira, M.C., Marvão, M.R., and Rocha, J., 2002, An optimised method to determine the degree of acetylation of chitin and chitosan by FTIR spectroscopy: International Journal of Biological Macromolecules, v. 31, p. 1-8.

Ehleringer, J.R., Cerling, T.E., and Helliker, B.R., 1997, C 4 photosynthesis, Atmospheric $\mathrm{CO}_{2}$, and climate: Oecologia, v. 112, p. 285-299.

Gröcke, D.R., Schimmelmann, A., Elias, S., and Miller, R.F., 2006, Stable hydrogen-isotope ratios in beetle chitin: preliminary European data and re-interpretation of North American data: Quaternary Science Reviews, v. 25, p. 1850-1864.

Hodgins, G.W.L., Thorpe, J.L., Coope, G.R., and Hedges, R.E.M., 2001, Protocol development for purification and characterization of subfossil insect chitin for stable isotopic analysis and radiocarbon dating: Radiocarbon, v. 43, p. 199-208.

Jeuniaux, C., 1971, Chitinous structures, in Florkin, M., and Stotz, E., eds., Comprehensive biochemistry, v. 26C, Amsterdam, Elsevier, p. 595-632.

Koopman, K.F., 1982, Biogeography of the bats of South America, in Mares, A.A., and Genoways, H., eds., Mammalian biology in South America, Special Publications, Pymatuning Laboratory of Ecology, University of Pittsburgh, v. 6, p. 273-302.

Lee, Y.F., and McCracken, G.F., 2002, Foraging activity and food resource use of Brazilian free-tailed bats, Tadarida brasiliensis (Molossidae): Ecoscience, v. 9, p. 306-313.

Maher, L.J., 2006, Environmental information from guano palynology of insectivorous bats of the central part of the United States of America: Palaeogeography, Palaeoclimatology, Palaeoecology, v. 237, p. 19-31.

McFarlane, D.A., Keeler, R.C., and Mizutani, H., 1995, Ammonia volatilization in a Mexican bat cave ecosystem: Biogeochemistry, v. 30 , p. $1-8$.

McFarlane, D.A., Lundberg, J., and Fincham, A.G., 2002, A late Quaternary paleoecological record from caves of southern Jamaica, West Indies: Journal of Cave and Karst Studies, v. 64, p. $117-125$.

Miller, R.F., Fritz, P., and Morgan, A.V., 1988, Climatic implications of D/H ratios in beetle chitin: Palaeogeography, Palaeoclimatology, Palaeoecology, v. 66, p. 277-288.

Mizutani, H., McFarlane, D.A., and Kabaya, Y., 1992a, Carbon and nitrogen isotopic signatures of bat guanos as a record of past environments: Mass Spectroscopy, v. 40, p. 67-82.

Mizutani, H., McFarlane, D.A., and Kabaya, Y., 1992b, Nitrogen and carbon isotope studies of a bat guano core from Eagle Creek Cave, Arizona, USA: Mass Spectrometry, v. 40, p. 57-65.

Mizutani, H., and Wada, E., 1988, Nitrogen and carbon Isotope ratios in seabird rookeries and their ecological Iimplications: Ecology, v. 69, p. $340-349$.

Motz, J.E., 2000, Oxygen and hydrogen isotopes in fossil insect chitin as paleoenvironmental indicators [PhD dissertation]: Waterloo, University of Waterloo, $152 \mathrm{p}$.

Nassar, J.M., Beck, H., Sternberg, L.S.L., and Fleming, T.H., 2003, Dependence on cacti and agaves in nectar-feeding bats from Venezuelan arid zones: Journal of Mammalogy, v. 84, p. 106-116.

Paruelo, J.M., and Lauenroth, W.K., 1996, Relative abundance of plant functional types in grasslands and shrublands of North America: Ecological Applications, v. 6, p. 1212-1224. 
Pinder, III, J.E., and Kroh, G.C., 1987, Insect herbivory and photosynthetic pathways in old-field ecosystems: Ecology, v. 68, p. 254-259.

Schimmelmann, A., 1991, Determination of the concentration and stable isotopic composition of nonexchangeable hydrogen in organic matter: Analytical Chemistry, v. 63, p. 2456-2459.

Schimmelmann, A., and DeNiro, M.J., 1986a, Stable isotopic studies on chitin, measurements on chitin/chitosan isolates and d-glucosamine hydrochloride from chitin, in Muzzarelli, R., Jeuniauz, C., and Gooday, G., eds., Chitin in nature and technology, New York, Plenum, p. 357-364.

Schimmelmann, A., and DeNiro, M.J., 1986b, Stable isotopic studies on chitin. II: The ${ }^{13} \mathrm{C} /{ }^{12} \mathrm{C}$ and ${ }^{15} \mathrm{~N} /{ }^{14} \mathrm{~N}$ ratios in arthropod chitin: Contributions in Marine Science, v. 29, p. 113-130.

Schimmelmann, A., DeNiro, M.J., Poulicek, M., Voss-Foucart, M.F., Goffinet, G., and Jeuniaux, C., 1986, Stable isotope composition of chitin from arthropods recovered in archaeological contexts as palaeoenvironmental indicators: Journal of Archaeological Science, v. 13 , p. $553-566$.

Schimmelmann, A., Miller, R.F., and Leavitt, S.W., 1993, Hydrogen isotopic exchange and stable isotope ratios in cellulose: Wood, chitin, and amino compounds: Geophysical Monograph-American Geophysical Union, v. 78, p. 367-367.

Schimmelmann, A., Wintsch, R.P., Lewan, M.D., and DeNiro, M.J., 1998, Chitin: Forgotten source of nitrogen: From modern chitin to thermally mature kerogen: Lessons from nitrogen isotope ratios, in Stankiewicz, B.A., and van Bergen, P.F., eds., Nitrogen-containing macromoleculesin the biosphere and geosphere, ACS Symposium Series 707, Washington, D.C., American Chemical Society, p. $226-242$.

Schwinning, S., Davis, K., Richardson, L., and Ehleringer, J.R., 2002, Deuterium enriched irrigation indicates different forms of rain use in shrub/grass species of the Colorado Plateau: Oecologia, v. 130, p. $345-355$.

Schwinning, S., Starr, B.I., and Ehleringer, J.R., 2003, Dominant cold desert plants do not partition warm season precipitation by event size: Oecologia, v. 136, p. 252-260.

Sealy, J.C., van der Merwe, N.J., Lee-Thorp, J.A., and Lanham, J.L., 1987, Nitrogen isotopic ecology in southern Africa: implications for environmental and dietary tracing: Geochimica et Cosmochimica Acta, v. 51, p. 2707-2717.

Seoudi, R., Nada, A.M.A., Elmongy, S.A., and Hamed, S.S., 2005, Fourier transform infrared spectroscopic and AC electrical conductivity studies of chitin and its derivatives: Journal of Applied Polymer Science, v. 98, p. 936-943.

Shahack-Gross, R., Berna, F., Karkanas, P., and Weiner, S., 2004, Bat guano and preservation of archaeological remains in cave sites: Journal of Archaeological Science, v. 31, p. 1259-1272.

Sponheimer, M., Robinson, T., Ayliffe, L., Roeder, B., Hammer, J., Passey, B., West, A., Cerling, T., Dearing, D., and Ehleringer, J., 2003, Nitrogen isotopes in mammalian herbivores: hair $\delta^{15} \mathrm{~N}$ values from a controlled feeding study: International Journal of Osteoarchaeology, v. 13 , p. $80-87$.
Stankiewicz, B.A., Briggs, D.E.G., Evershed, R.P., Flannery, M.B., and Wuttke, M., 1997, Preservation of chitin in 25-million-year-old fossils: Science, v. 276, $1541 \mathrm{p}$.

Stankiewicz, B.A., Poinar, H.N., Briggs, D.E.G., Evershed, R.P., and Poinar, G.O., 1998, Chemical preservation of plants and insects in natural resins, in Proceedings, Biological Sciences, v. 265, p. 641-647.

Thompson, R.S., Whitlock, C., Bartlein, P.J., Harrison, S.P., and Spaulding, W.G., 1993, Climatic changes in the western United States since 18,000 yr BP, in Wright, H.E. Hr., Kutzbach, J.E., Webb, III, T., Ruddiman, W.F., Street-Perrott, F.A., and Bartlein, P.J., eds., Global climates since the last glacial maximum, Minneapolis, University of Minnesota Press, p. 468-513.

Tripp, J.A., Higham, T.F.G., and Hedges, R.E.M., 2004, A pretreatment procedure for the AMS radiocarbon dating of sub-fossil insect remains: Radiocarbon, v. 46, p. 147-154.

Van de Velde, K., and Kiekens, P., 2004, Structure analysis and degree of substitution of chitin, chitosan and dibutyrylchitin by FT-IR spectroscopy and solid state ${ }^{13} \mathrm{C}$ NMR: Carbohydrate Polymers, v. 58 , p. $409-416$.

Wanjun, T., Cunxin, W., and Donghua, C., 2005, Kinetic studies on the pyrolysis of chitin and chitosan: Polymer Degradation and Stability, v. 87 , p. $389-394$

Warren, P.H., and Gaston, K.J., 1992, Predator-prey ratios: A special case of a general pattern?: Royal Society of London B, v. 338, p. 113-130.

Wassenaar, L.I., and Hobson, K.A., 2000, Improved method for determining the stable-hydrogen isotopic composition $(\delta \mathrm{D})$ of complex organic materials of environmental interest: Environmental Science and Technology, v. 34, p. 2354-2360.

Wassenaar, L.I., and Hobson, K.A., 2003, Comparative equilibration and online technique for determination of non-exchangeable hydrogen of keratins for use in animal migration studies: Isotopes in Environmental and Health Studies, v. 39, p. 211-217.

Webb, S.C., Hedges, R.E.M., and Simpson, S.J., 1998, Diet quality influences the $\delta^{13} \mathrm{C}$ and $\delta^{15} \mathrm{~N}$ of locusts and their biochemical components: Journal of Experimental Biology, v. 201, p. 2903-2911.

Wilkins, K.T., 1989, Tadarida brasiliensis: Mammalian Species, v. 331, p. $1-10$.

Wurster, C.M., McFarlane, D.A., and Bird, M.I., 2007, Spatial and temporal expression of vegetation and atmospheric variability from stable carbon and nitrogen isotope analysis of bat guano in the southern United States: Geochimica et Cosmochima Acta, v. 71, p. 3302-3310.

Wurster, C.M., Patterson, W.P., McFarlane, D.A., Wassenaar, L.I., Hobson, K.A., Athfield, N.B., and Bird, M.I., 2008, Stable carbon and hydrogen isotopes from bat guano in the Grand Canyon, USA, reveal Younger Dryas and 8.2 ka events: Geology, v. 36, p. 683-686.

Wurster, C.M., Bird, M.I., Bull, I.D., Bryant, C., and Ascough, P., 2009, A protocol for radiocarbon dating tropical subfossil cave guano: Radiocarbon, v. 51, p. 1-10.

Wurster, C.M., Saiz, G., Calder, A., and Bird, M.I., 2010, Recovery of organic matter from mineral-rich sediment and soils for stable isotope analyses using static dense media: Rapid Communications in Mass Spectrometry, v. 24, p. 165-168. 